\title{
THE CONTRIBUTION OF SENTENCE STRUCTURE COMPETENCE AND SELF- EFFICACY TO WRITING ABILITY
}

\author{
Lisa Dwi Nurhayati, Muh. Asrori, Endang Setyaningsih \\ English Education Department \\ Faculty of Teacher Training and Education \\ Sebelas Maret University of Surakarta
}

Email: lyssa_dwee@yahoo.com

\begin{abstract}
The aim of this study is to find out (1) the contribution of sentence structure competence to writing ability; (2) the contribution of self-efficacy to writing ability; (3) the contribution of sentence structure competence and self-efficacy to writing ability. The method of this study is correlation method. To fulfill the aim of study, 30 students out of 512 of senior high school students were taken as sample by cluster random sampling and random sampling. The instruments used to collect the data are test and questionnaire. The data obtained are analyzed by Pearson Product Moment Formula and Multiple Regression and Correlation. The result of this study indicates that sentence structure competence and selfefficacy give significant positive contribution to writing ability; both partially and simultaneously. It means sentence structure competence and self-efficacy can be used to predict writing ability. The result also indicates self-efficacy has greater contribution than sentence structure competence. Therefore, self-efficacy should be paid more attention.
\end{abstract}

Keywords: contribution, sentence structure competence, self-efficacy, writing ability

The word ability means "The mental or physical capacity, power or skill required to do something" (Merriam-webster dictionary, 2013; thefreedictionary 2013). Thus, writing ability in a simple way is capacity to produce a piece of writing. Widdowson (1978) states writing is related to a language expressed through visual medium. He adds writing is a productive skill. It means the writers are required to produce language in written forms. Harris (1993: 34) says, "Writing is a difficult activity which is taking several processes. It is full of starts and stops, punctuated by long pauses for reflection or by the need to regenerate concentration. White and Arndt in Sweeting (2010: 1) add:

"Writing is far from being a simple matter of transcribing language into written symbols; it is a thinking process in its own right. It demands conscious intellectual effort, which usually has to be sustained over a considerable period of time."

According to Hart and Reinking (1986), a good piece of writing should be built from words to sentences, sentences to paragraphs, and paragraphs to a text. Byrne (1997) adds that writing is forming symbols, those symbols are arranged to form words, words have to be arranged into sentences, and those sentences are linked together in certain ways to form a coherent text. In order to produce a good writing, the writers should notice several components of writing, such as: content, process of writing, audience, purpose, word choice, organization, mechanics, grammar, and syntax (Raimes, 1983). Thus, in a more detail, writing ability is the capacity of forming symbols to words, words into sentences, and sentences into paragraphs according to certain convention, 
such as: content, organization, language use, vocabulary, and mechanics.

Sentence structure competence is one of the aspects which need to be owned by students to produce a good writing. Competence in general means "One's underlying knowledge of a system, event, or fact" (Brown, 2000: 30). Anglin (2013: 1) says, "Sentence structure is the order and arrangement of the clauses in a sentence, which is a group of words that express a complete thought." Lambrecht (1994: 10) argues, "Sentence structure is a component of grammar or specifically of sentence grammar. It is concerned with the way such content is transmitted and the organization of sentence within a discourse."

An effective sentence should be constructed from words, phrase, and clause (Newby, 1988). Halliday (1994: 24) adds, "A sentence consists of clauses, which consists of phrases, which consist of words, which consists of morphemes." Hence, it can be concluded that sentence structure competence is knowledge of a series of words, phrases and clauses to express grammatically complete expression of a single thought.

In relation to writing, Kress in Harris (1993) says sentence is the fundamental basis of written text. An important aspect of writers is their ability to control and construct effective sentences. Hedge (2008) says, "Successful writing depends on the ability to produce clear-correct sentences." Harmer (2001: 13) argues, "The order of words is essential to successful communication whether in writing or in speech." Considering the importance of sentence in writing, students must pay extra attention on the structure of sentence.

Another thing which can affect writing ability is self-efficacy. Bandura (1982: 122) sates, "Self-efficacy is concerned with judgments of how well one can execute courses of action required to deal with prospective situations." Elliot, Stephen, Kratochwill, Cook, and Travers (2000) add, "Self-efficacy refers to people's beliefs of their capabilities to exert control over aspects of their lives on a particular task."

According to Pajares (1996: 6), "Selfefficacy helps to determine the effort they will expend on a certain activity. It also determines how long they will preserve when they are confronting obstacles and how resilient they will be in facing difficult situations." This is in line with Bandura in Landry (1993: 12) who states, "Efficacy beliefs influence the courses of action people choose to pursue, how much effort they put forth in given endeavors, how long they will persevere in the face of obstacles and failures." In conclusion, self-efficacy is people's judgments on their capabilities in doing action, giving effort, and confronting obstacles to fulfill goals in a particular task.

In relation to writing, "Students who feel competent in writing should be more likely to choose to write, expend effort, and persist at writing tasks than students who doubt their capabilities" (Meier, McCarthy, \& Schmeck; Shell, Murphy, \& Bruning in Schunk \& Swartz, 1993). According to Woolfolk (2009) students with high sense of efficacy in a specific task (I am good at writing) tend to think that their failures lie on their lack of effort (I had to re-examine my writing task). Meanwhile, students with low sense of efficacy (I am bad at writing) tend to think that their failures lie on the 
lack of capabilities. Thus, self-efficacy is people's judgments on their capabilities in doing action, giving effort, and confronting obstacles to fulfill goals in a particular task.

Based on the explanation, in order to have a good writing ability, students should write sentences correctly by having the sentence structure competence. In addition, students' belief on their capability in writing is needed to enhance their writing performance. Therefore, this study is conducted to find out the contribution of sentence structure competence to writing ability; the contribution of self-efficacy to writing ability; and the contribution of sentence structure competence and selfefficacy to writing ability.

\section{RESEARCH METHODS}

The method of this research is correlation method. Correlation method is used to predict the contribution of independent variable to dependent variable. In this research, there are two kinds of variables, independent variable and dependent variable. The independent variables are sentence structure competence $\left(\mathrm{X}_{1}\right)$ and self-efficacy $\left(\mathrm{X}_{2}\right)$, while the dependent variable is writing ability $(\mathrm{Y})$. The relationship between those variables can be drawn as follows: there is a positive correlation between sentence structure competence $\left(\mathrm{X}_{1}\right)$ and writing ability $(\mathrm{Y})$; there is a positive correlation between selfefficacy $\left(\mathrm{X}_{2}\right)$ and writing ability $(\mathrm{Y})$; and there is a positive correlation between sentence structure competence $\left(\mathrm{X}_{1}\right)$, selfefficacy $\left(\mathrm{X}_{2}\right)$, simultaneously and writing ability (Y).

The population of this research is the eleventh-grade students of a Vocational State High School. The researcher takes randomly 5 classes from five departments, and then takes randomly 6 students from each class.
Therefore, the total sample is 30 students out of 512 students.

The data are collected by using questionnaire and test. The questionnaire is used to collect the data of self-efficacy, and the test is used to collect the data of sentence structure competence and writing ability. The instruments of sentence structure competence and self-efficacy are tried out to non-sample students to find out the validity and reliability. To test the validity and reliability of sentence structure competence, the researcher uses point-biserial correlation and KR-20 formula. Meanwhile, to test the validity and reliability of self-efficacy, the researcher uses Alpha Cronbach formula. The instrument of sentence structure competence consists of 30 items, and the instrument of self-efficacy consists of 40 items. To find out whether the instrument of writing ability can be understood by the students, the researcher used readability test. The result of readability test shows most of students can understand the information within the writing ability instrument.

Before analyzing the data, it is necessary to examine the data. The prerequisite tests cover normality and linearity and significance. Normality test is conducted to find out whether the data are in a normal distribution. Linearity and significance test is aimed to know whether two variables have significant linear regression. The data are analyzed by using Pearson Product Moment Formula and Multiple Regression and Correlation. Pearson Product Moment Formula is conducted to find out the correlation between sentence structure competence $\left(\mathrm{X}_{1}\right)$ and writing ability $(\mathrm{Y})$; selfefficacy $\left(\mathrm{X}_{2}\right)$ and writing ability (Y). Meanwhile, Multiple Regression and Correlation is conducted to find out the correlation between sentence structure competence $\left(\mathrm{X}_{1}\right)$, self-efficacy $\left(\mathrm{X}_{2}\right)$, and writing ability $(\mathrm{Y})$. 


\section{RESULT FIDNINGS AND DISCUSSIONS}

The obtained data are sentence structure competence, self-efficacy, and writing ability. Those data can be described in Table 1.

Before testing the hypothesis, the data should be examined by conducting normality and linearity and significance regression test. The result of normality test can be described in Table 2.

The result shows that the highest value of sentence structure competence $\left(\mathrm{X}_{1}\right)$ is $0.093<0.161$; self-efficacy $\left(\mathrm{X}_{2}\right)$ is $0.119<0.161$; writing ability (Y) is $0.1409<0.161$. Therefore, it can be concluded the data of sentence structure competence, self-efficacy, and writing ability are in normal distribution.

The result of linearity and significance of regression test can be described in Table 3. The result shows the linearity of $\mathrm{X}_{1} \mathrm{Y}$ is $1.74<2.41$, and the linearity of $\mathrm{X}_{2} \mathrm{Y}$ is $1.33<3.51$. Meanwhile, the significance level of $\mathrm{X}_{1} \mathrm{Y}$ is $8.33>4.20$ and the significance level of $X_{2} Y$ is 1816>4.20. Therefore, it can be concluded that the regression of $\mathrm{X}_{1} \mathrm{Y}$ and $\mathrm{X}_{2} \mathrm{Y}$ is linear and significant.

The result of simple regression analysis of $X_{1}$ and $Y$ shows the value of coefficient $\mathrm{a}=48.62$, and $\mathrm{b}=0.93$. Therefore, the regression equation of $\mathrm{X}_{1}$ on $\mathrm{Y}$ is $\hat{\mathrm{Y}}=$ $48.62+0.93 X_{1}$. The first hypothesis testing shows the coefficient correlation between sentence structure competence $\left(\mathrm{X}_{1}\right)$ and writing ability (Y) is 0.479 . After being calculated by using t-test, the value of $\mathrm{t}$ obtained $\left(t_{0}\right)$ is 2.886 . The value of t-table $\left(t_{t}\right)$ at the level of significance $\alpha=0.05$ for $\mathrm{N}=30$ is 1.70. It means $t_{0}$ is greater than $t_{t}$ $(2.886>1.70)$. Therefore, it can be said the coefficient correlation is significant. The coefficient of determination $\left(\mathrm{r}^{2}\right)$ between sentence structure competence and writing ability is 0.229 . It means $22.9 \%$ variance of writing ability is determined by sentence structure competence and $77.1 \%$ variance of writing ability is determined by other factors.

Funk, McMahan \& Day (1991: 3) state, "Sentence is the basic unit communication in all forms of English. One of the most important skills a writer can have is the ability to compose clear, complete sentences." Kress in Harris (1993) adds sentence is the fundamental basis of written text. An important aspect of writers is their ability to control and construct effective sentences. Being able to create correct sentence structure helps students to deliver their ideas to readers in a written form. According to Weber \& Brizee (2013), the writers should create varied sentence structure to make their writing interesting. In addition, varied sentence structure emphasizes the writers' idea and reduces repetitive words. Long sentences can contain a lot of information and short sentences can maximize important points. The analysis result shows there is a significant positive correlation between sentence structure competence $\left(\mathrm{X}_{1}\right)$ and writing ability $(\mathrm{Y})$. 
Table 1. Description of each Variable

\begin{tabular}{lccc}
\hline & $\mathrm{X}_{1}$ & $\mathrm{X}_{2}$ & $\mathrm{Y}$ \\
\hline Highest & 25 & 133 & 86 \\
Lowest & 10 & 92 & 56 \\
Mean & 18.20 & 105.97 & 64.83 \\
Mode & 19.42 & 96.89 & 63.71 \\
Median & 18.75 & 103.5 & 64.73 \\
Standard Deviation & 3.66 & 10.67 & 8.95 \\
\hline
\end{tabular}

Table 2. Table of Normality Test

\begin{tabular}{lccc}
\hline & $\mathrm{X}_{1}$ & $\mathrm{X}_{2}$ & $\mathrm{Y}$ \\
\hline $\mathrm{N}$ & 30 & 30 & 30 \\
Mean & 18.43 & 106.167 & 65.67 \\
Standard Deviation & 3.431 & 10.629 & 6.665 \\
$\mathrm{~L}_{\mathrm{o}}$ & 0.093 & 0.119 & 0.1409 \\
$\mathrm{~L}_{\mathrm{t}}$ & 0.161 & 0.161 & 0.161 \\
\hline
\end{tabular}

Table 3. Table Linearity and Significance of Regression $X_{1} Y$ and $X_{2} Y$

\begin{tabular}{lcc}
\hline & $\mathrm{X}_{1} \mathrm{Y}$ & $\mathrm{X}_{2} \mathrm{Y}$ \\
\hline $\mathrm{F}_{\mathrm{o}}$ Linearity & 1.74 & 1,33 \\
$\mathrm{~F}_{\mathrm{t}}$ & 2.41 & 3.51 \\
$\mathrm{~F}_{\mathrm{o}}$ Significance & 8.33 & 18.16 \\
$\mathrm{~F}_{\mathrm{t}}$ & 4.20 & 4.20 \\
\hline
\end{tabular}

The result of simple regression analysis of $\mathrm{X}_{2}$ and $\mathrm{Y}$ shows the value of coefficient $a=24$, and $b=0.39$. Therefore, the regression equation of $\mathrm{X}_{2}$ on $\mathrm{Y}$ is $\hat{\mathrm{Y}}=24+$ $0.39 X_{2}$. The result of second hypothesis testing shows the correlation coefficient ( $\mathrm{r}$ ) between self-efficacy $\left(\mathrm{X}_{2}\right)$ and writing ability (Y) is 0.627 . After being calculated by using $\mathrm{t}$-test, the value of $\mathrm{t}$-obtained $\left(\mathrm{t}_{\mathrm{o}}\right)$ is 4.262 . The value of t-table $\left(\mathrm{t}_{\mathrm{t}}\right)$ at the level of significance $\alpha=0.05$ for $\mathrm{N}=30$ is 1.70 . It means $t_{o}$ is higher than $t_{t}(4.262>1.70)$. Therefore, it can be said the coefficient of correlation is significant. The coefficient determination $\left(\mathrm{r}^{2}\right)$ between self-efficacy and writing ability is 0.393 . It means $39.3 \%$ variance of writing ability is determined by self-efficacy and $60.7 \%$ variance of writing ability is determined by other factors.
Pajares (2003), in his synthesis research finds out students' belief in their writing capabilities influence their writing motivation and writing outcomes. Students who believe that they are capable in writing tend to be motivated in writing and produce a good writing. Meier, McCarthy, \& Schmeck (1984); Shell, Murphy, \& Burning (1989) in Schunk \& Swartz (1993) define students with high sense of efficacy in writing will expend their best effort at writing. In addition, they will persist at writing task even though they face any obstacles in the process of writing. On the other hand, students with low sense of efficacy will not give their best effort and tend to give up when they face any obstacles. The analysis result shows there is a significant positive correlation between selfefficacy $\left(\mathrm{X}_{2}\right)$ and writing ability $(\mathrm{Y})$. 
The result of third hypothesis testing shows the multiple linear regression analysis of sentence structure competence, selfefficacy, and writing ability $\left(\mathrm{a}_{1}, \mathrm{a}_{2}\right.$, and $\mathrm{a}_{\mathrm{o}}$ ) are $0.225,0.346$, and 24.939 . Therefore, the multiple linear regression equation of $\mathrm{Y}$ on $\mathrm{X}_{1}$ and $\mathrm{X}_{2}$ is $\hat{\mathrm{Y}}=24.939+0.225 X_{1}+$ $0.346 X_{2}$. The testing result of the significant of regression is 9.038 . The result is compared to F-table at the significance level of 5\% and degree of freedom $(\mathrm{df}=2: 27)$ is 5.49 . It means that $F_{o}$ is higher than $F_{t(2,27)}$ $(9.038>5.49)$. It can be concluded that the multiple linear regression is significant.

The computation shows the correlation coefficient (R) between sentence structure competence $\left(\mathrm{X}_{1}\right)$ and self-efficacy $\left(\mathrm{X}_{2}\right)$ simultaneously and writing ability $(\mathrm{Y})$ is 0.633. After being calculated, the value of Fobtained $\left(\mathrm{F}_{\mathrm{o}}\right)$ is 9.038 . The value of F-table $\left(F_{t}\right)$ at the level of significance $\alpha=0.05$ for $\mathrm{N}=30$ and df $2: 27$ is 3.35 . It means $F_{o}$ is higher than $F_{t}(9.038>3.35)$. Therefore, it can be concluded that the coefficient of multiple correlation is significant. The coefficient of determination $\left(\mathrm{R}^{2}\right)$ of sentence structure competence $\left(\mathrm{X}_{1}\right)$ and self-efficacy $\left(\mathrm{X}_{2}\right)$ toward writing ability $(\mathrm{Y})$ is 0.401 . It means $40.1 \%$ variance of writing ability is determined by sentence structure competence and self-efficacy, while $59.9 \%$ variance of writing ability is determined by other factors.

Widdowson (1978: 62) states, "Writing is the act of making up correct sentences and transmitting them through the visual medium as mark on paper." Bell and Burnaby in Nunan (1989) adds writing is a complex activity which requires the writer to have a great control of several variables in writing. One of those variables is sentence structure. Hedge (2008: 10) says, "Successful writing depends on the ability to produce clear-correct sentences." Harmer (2001: 13) argues, "The order of words (sentence structure) is essential to successful communication whether in writing or in speech."

Another factor which can give contribution to writing ability is self-efficacy. According to Pajares and Valiante (1997); Lavelle (2006) in Matoti and Shumba (2011: 110), "By having sufficient self-belief in their writing ability, individuals may have greater interest in writing, make more constant efforts, and show greater perseverance and resiliency in the face of difficulty when they are conducting a writing task." The analysis result shows there is a significant positive correlation between sentence structure competence (X1), self-efficacy (X2), simultaneously and writing ability (Y).

\section{CONCLUSIONS AND SUGGESTIONS}

Reflecting to the result findings, this study can be concluded as follows: First, there is a significant positive correlation between sentence structure competence and writing ability. By having the competence of sentence structure, students will easily construct effective sentences which represent their ideas and thought. Therefore, what they write in their writing can be understood by readers. On the other hand, those who do not have the competence of sentence structure will have difficulties in constructing sentences; thus, their ideas cannot be delivered clearly to readers.

Second, there is a significant positive correlation between self-efficacy and writing ability. Students who are efficacious tend to believe in themselves that they are able to produce a good writing. They will give their best effort and find solutions for every single difficulty. In addition, they will be motivated in doing difficult task and activity. On the other hand, those who do not have high sense of efficacy tend to give up easili when they 
face difficulty. Moreover, they will not give their best effort to produce a pice of writing. Third, there is a significant positive correlation between sentence structure competence, self-efficacy, simultaneously and writing ability. Students who are competent in creating effective sentences and efficacious in writing tend to produce a good piece of writing.

The result of single correlation indicates the contribution of self-efficacy to writing ability is greater than sentence structure competence to writing ability, $(0.627)>(0.479)$. Therefore, self-efficacy should be paid more attention. A similar study conducted by Hetthong (2013) shows the coefficient correlation between selfefficacy and writing performance is 0.71 . The result indicates there is a high positive correlation between self-efficacy and writing performance.

Considering that sentence structure competence and self-efficacy give a significant contribution to writing ability, teachers should give attention to students' sentence structure competence and selfefficacy to improve their writing ability. In order to improve students' sentence structure competence, teachers should create an interesting and effective activity. They can conduct a learning activity based on situational context. Teachers provide a series of pictures. Students should create sentences which explain the situation based on the pictures. Meanwhile, to improve students' self-efficacy, teachers should be role models for their students since their behavior and suggestion can motivate their students. Teachers can maintain student's self-efficacy in writing by giving suggestion and persuasion that students can overcome any difficulties and improve their writing ability. In addition, teachers should give appropriate reinforcement to students based on the students' performance to enhance their selfefficacy.

\section{BIBLIOGRAPHY}

(2013). Merriam-webster dictionary. Retrieved from: http://www.learnersdictionary.com/d efinition/ability

(2013). The free dictionary. Retrieved from: http://www.thefreedictionary.com/ab ility

Anglin, M.R. (2013). What is sentence structure?. Sparks: Conjecture Corporation. Retrieved from: http://www.wisegeek.org/what-issentence-structure.htm

Bandura, A. (1982). Self-efficacy mechanism in human agency. American Psychologist, 32, 122-147. Retrieved from: http://www.uky.edu/ eushe2/Bandur a/Bandura1982AP.pdf

Brown, D. H. (2000). Principle of language and learning and teaching. New York: Addison Wesley Longman, Inc.

Byrne, D. (1997). Teaching writing skill. London: Longman.

Elliot, S. N., Kratochwill, T. R., Cook, J. L., \& Travers, J.F. (2000). Educational psychology: Effective teaching, effective learning. New York: McGrawHill. 
Funk, R., McMahan, E., \& Day, S.X. (1991). The elements of grammar for writers. New York: McMillan.

Halliday, M.A.K. (1994). An introduction to functional grammar. London: Arnold.

Harmer, J. (2001). The practice of English language teaching. London: Longman.

Harris, J. (1993). Introducing writing. London: Penguin English.

Hart, A.W. \& Reinking, J.A. (1997). Writing for career-education students. New York: Saint Martin's Press, Inc.

Hedge, T. (2008). Resource books for teachers: Writing. Oxford: Oxford University Press.

Hetthong, R. (2013). Does writng selfefficacy correlate with and predict writing performance? International Journal of Applied Linguistics and English Literature, 2, 157-167. Retrieved from: http://www.academia.edu/2352912/

Does_Writing_Selfefficacy_Correlate_with_and_Predic t_Writing_Performance

Lambrecht, K. (1996). Information structure and sentence form: Topic, focus, and the mental representations of discourse referents. Cambridge: Cambridge University Press.

Landry, C.C (2003). Self-Efficacy, motivation, and outcome expectation correlates of college students' intention certainty. Retrieved from: http://etd.lsu.edu/docs/available/etd0409103084327/unrestricted/Landry_dis.pdf

Matoti, S. \& Shumba, A. (2011). Assessing the writing efficacy of post-graduate students at a University of Technology in South Africa. $J$ Soc Sci, 29(2), 109-118. Retrieved from: http://www.krepublishers.com/02Journals/JSS/JSS-29-0-000-11Web/JSS-29-2-000-11-AbstPdf/JSS-29-2-109-11-1233-MatotiS/JSS-29-2-109-11-1233-Matoti-STt.pdf.

Newby, M. (1988). The structure of English: $A$ handbook of English grammar. Cambridge: Cambridge University Press.

Nunan, D. (1989). Designing tasks for the communicative classroom. Cambridge: University of Cambridge.

Pajares, F. (1996). Self-efficacy beliefs in academic setting. Review of Educational Research, 66, 543-578. Retrieved from: http.uky.edu/ eushe2/Pajares/Pajares 1996RER

Pajares, F. (2003). Self-efficacy beliefs, motivation, and achievement in writing: A review of the literature. Reading and Writing Quarterly, 19, 139-158. doi: $10.1080 / 10573560390143085$

Raimes, A. (1983). Teaching techniques in English as a second language: Techniques in teaching writing. Oxford: Oxford University Press.

Schunk, D. H. , \& Swartz, C. W. (1993). Goals and progress feedback: effects on self-efficacy and writing achievement. Contemporary Educational Psychology, 18(3), 337354. Retrieved from: http://elsevier.com

Sweeting, A. (2010). Practical classroom activities for changing learners' 
attitudes towards narrative writing. EA Journal, 26, 91-94. Retrieved from:

http://qa.englishaustralia.com.au/ind ex.cgi? $=$ hcatfuncs $\& \mathrm{PT}=$ sl $\& \mathrm{X}=$ getd oc\&Lev1=pub_EAJ_26-

$1 \&$ Lev $2=$ SWEETING.

Weber, R., Brizee, A. (2013). Strategies for variation. Retrieved from: https://owl.english.purdue.edu/owl/re source/573/01/

Widdowson, H. G. (1978). Teaching language as communication. Oxford: Oxford University Press.

Woolfolk, A. (2009). Educational psychology: Active learning edition. (Soetjipto, H.P., \& Soetjipto, A.M, Trans) Yogyakarta: Pustaka Belajar. (Original work published 2008) 